J. Perinat. Med. 6 (1978) 206

\title{
A new method to decrease the risk of intrapartum infection
}

\section{Erich Saling}

Unit of Perinatal Medicine - The Free University of Berlin, Department of Obstetrics, Berlin-Neukölln

Ascending infections, especially those following the rupturing of membranes, have occupied the obstetricians for generations because of the increased risk to mother and infants.

With the development of perinatal medicine during the last 15 years this risk has increased because of the introduction of intensive monitoring during labor. Several studies have shown that the colonization of the amniotic fluid increases rapidly within a few hours after the rupturing of membranes $[4,11,19]$. The use of intensive monitoring techniques (cardiotocography, fetal blood sampling, more internal examinations) adds to the introduction of organisms $[8,9,12,15]$. This is demonstrated in Fig. 1. While prophylactic use of

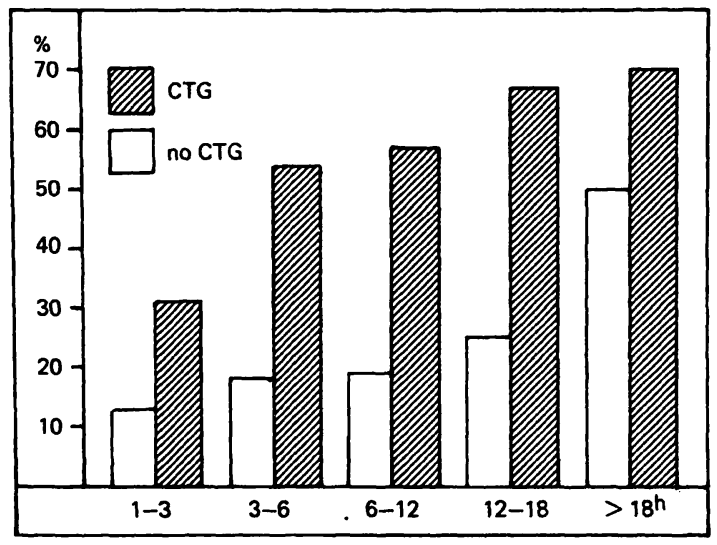

Fig. 1. Frequency of colonized amniotic fluid samples as a function of the time between rupturing of membranes and delivery in births with and without cardiotocography. After DAHLER et al [9]. antibiotics will decrease the immediate risk to mother and infant [17] this is not considered an appropriate solution because of the selection of resistant organisms [19].

Therefore, we have sought a new approach which would allow to combat the ascension of organisms without increasing hospital infections. With initiation of intrapartum monitoring we introduce together with the scalp electrode for fetal heart monitoring a thin plastic catheter attached to the electrode (Fig. 2) through which a suitable disinfectant solution is slowly pumped throughout the subsequent period of delivery. Thus the birth canal is being constantly rinsed with the solution from the presenting part to the vulva. We use as the disinfectant an organic complex of polyvinylpyrrolidone with iodine (Trade Names: Betadine, Betaisodona $^{\mathbf{R}}$ ).

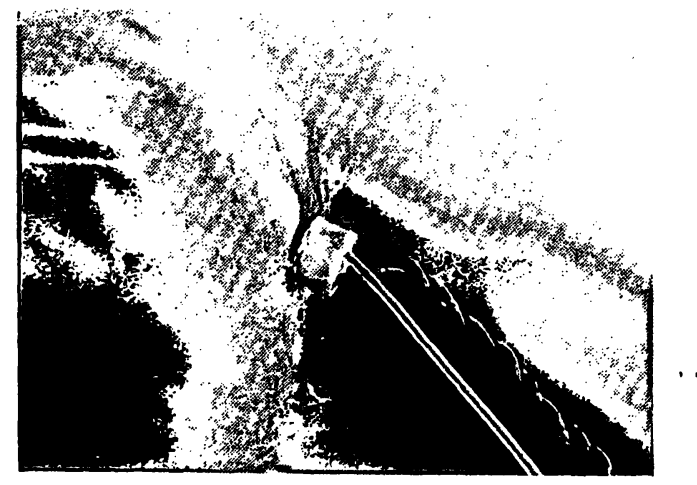

Fig. 2. The spiral ECG electrode is attached together with the catheter on the fetal scalp (demonstration on a newborn). Sample electrodes are available from SIEMENS AG D-852 Erlangen. 
The choice of the disinfectant was influenced by the following considerations: iodine has been among the most reliable disinfectants for decades; it is bactericidal, fungicidal, sporocidal, tuberculocidal, trichomonocidal, and virucidal for some viruses. Because of some properties (e.g. tissue irritation, allergic sensitization) it has found only limited use. Because of the complex bond of iodine in Betadine, it lacks the disadvantages of "free" iodine while the disinfectant action is preserved [16]. Betadine is extraordinarily well tolerated.

An increase in serum iodine following application of Betadine is, if any, far less and shorter than following tincture of iodine or LuGoL's solution $[1,2,21]$. Betadine is a suitable means of preoperative skin disinfection [6]. Local irritations are insignificant. According to PostlethwaIt and DiLloN [20] there was only one skin reaction in 666 patients undergoing pre-operative skin disinfection and BoGASH [5] saw only two cases of skin reaction in 5900 cases.

The use of Betadine in iodine-sensitized volunteers according to SHELANSKI [22] led to practically no reaction.

Betadine is also used therapeutically on sensitive tissues e.g. in the mouth $[7,26]$, for the treatment of urethritis [25] and, finally, as a $1 \%$ solution for peritoneal dialysis [13] and mediastinal irrigation [24]. A number of publications have dealt with its use in vagina, especially in the treatment of vaginitis. The first publication was in 1963 [23]; more recent reports were authored by BERNHARD, 1973 [3], MANEKSHA, 1974 [18] and HAUSER, 1975 [14]. The use of Betadine for pre-operative disinfection of the vagina was reported by DUIGNAN and LowE [10].

\section{Material and methods}

Between August and December 1976 all patients with cervical dilatation of $4 \mathrm{~cm}$ and less at the time of admission to the delivery room were entered into the study. Study patients and controls were alternated. Every other patient immediately after positioning in the labor bed underwent introduction of the fetal scalp electrode to which the catheter for the irrigation with disinfectant
Tab. I. Average number of vaginal and rectal examinations and fetal blood analyses per case in the two groups.

\begin{tabular}{llll}
\hline & $\begin{array}{l}\text { Vaginal } \\
\text { exami- } \\
\text { nations } \\
\text { per } \\
\text { patient }\end{array}$ & $\begin{array}{l}\text { Rectal } \\
\text { exami- } \\
\text { nations } \\
\text { per } \\
\text { patient }\end{array}$ & $\begin{array}{l}\text { Number } \\
\text { of fetal } \\
\text { blood } \\
\text { sampling } \\
\text { per } \\
\text { patient }\end{array}$ \\
\hline $\begin{array}{l}\text { Betadine } \\
\text { applied }\end{array}$ & 3.4 & 0.7 & 1.1 \\
$\begin{array}{l}\text { Betadine } \\
\text { not applied }\end{array}$ & 3.2 & 0.8 & 1.3 \\
\hline
\end{tabular}

was attached. Immediately after the application of the electrode we began with the administration of Betadine to the presenting part of the fetus. In order to accomplish an initially rapid coverage of the environment of the presenting part, ten drops per minute ( $=15 \mathrm{ml} /$ hour) were given during the first ten minutes. During the following four hours the dose was 4 drops per minute (= $6 \mathrm{ml} /$ hour) and from then on until delivery 2 drops per minute $(=3 \mathrm{ml} /$ hour) of the undiluted Betadine solution. In the control patients fetal scalp electrodes were positioned without the apparatus for the irrigation with a disinfectant. The other methods of intrapartum monitoring such as vaginal or rectal examinations and fetal scalp blood analysis were used similarly in both groups (Tab. I).

Body temperature was controlled by axillary measurement at 4 p.m. every day.

\section{Results and discussion}

Morbidity in the postpartum period is considered the most important parameter for infection associated with labor. Tab. II and Fig. 3 identify the cases with subfebrile $\left(37,0-37.9^{\circ} \mathrm{C}\right)$ and febrile $\left(\geqslant 38^{\circ} \mathrm{C}\right)$ temperatures.

Because of the importance of the latent period between rupture of membranes and associated ascension of organisms and the initiation of the Betadine irrigation of the vagina we evaluated only those cases in which the period between the rupturing of membranes and the positioning of the electrode was less than 3 hours. In most 
Tab. II. Breakdown of cases with postpartum morbidity.

\begin{tabular}{|c|c|c|c|c|c|c|c|c|c|c|}
\hline & \multicolumn{2}{|c|}{$\begin{array}{l}\text { None or minimal } \\
\text { a } \\
\text { No fever and } \\
\text { subfebrile } \\
\text { temperature } \\
0-6 \text { days }\end{array}$} & \multicolumn{2}{|c|}{$\begin{array}{l}\text { Minor } \\
\text { b } \\
\text { Fever } 1 \text { day and } \\
\text { subfebrile } \\
\text { temperature } \\
0-2 \text { days }\end{array}$} & \multicolumn{2}{|c|}{$\begin{array}{l}\text { Moderate } \\
\text { c } \\
\text { Fever } 2-4 \text { days } \\
\text { or fever } 1 \text { day and } \\
\text { subfebrile } \\
\text { temperature } 3-6 \\
\text { days or no fever } \\
\text { and subfebrile } \\
\text { temperature } \\
\geqslant 7 \text { days }\end{array}$} & \multicolumn{2}{|c|}{$\begin{array}{l}\text { Considerable } \\
\mathrm{d} \\
\text { Fever } \geqslant 10 \text { days }\end{array}$} & c \& & \\
\hline Betadine & $\mathrm{n}$ & $\%$ & $\mathrm{~m}$ & $\%$ & $\mathrm{n}$ & $\%$ & $\mathbf{n}$ & $\%$ & $\mathbf{n}$ & $\%$ \\
\hline $\begin{array}{l}\text { Applied } \\
n=127\end{array}$ & 117 & 92.1 & 4 & 3.1 & 6 & 4.7 & 0 & 0 & 6 & 4.7 \\
\hline $\begin{array}{l}\text { Not applied } \\
n=122\end{array}$ & 104 & 85.2 & 2 & 1.6 & 13 & 10.7 & 3 & 2.5 & 16 & 13.1 \\
\hline
\end{tabular}

$\chi^{2}$-Test: significant difference $(p<0.05)$

instances rupturing of membranes and electrode positioning occurred almost at the same time.

As seen in Tab. II and Fig. 3, 4 groups have been classified: minimal or no morbidity (Group a) were patients without fever or subfebrile temper-

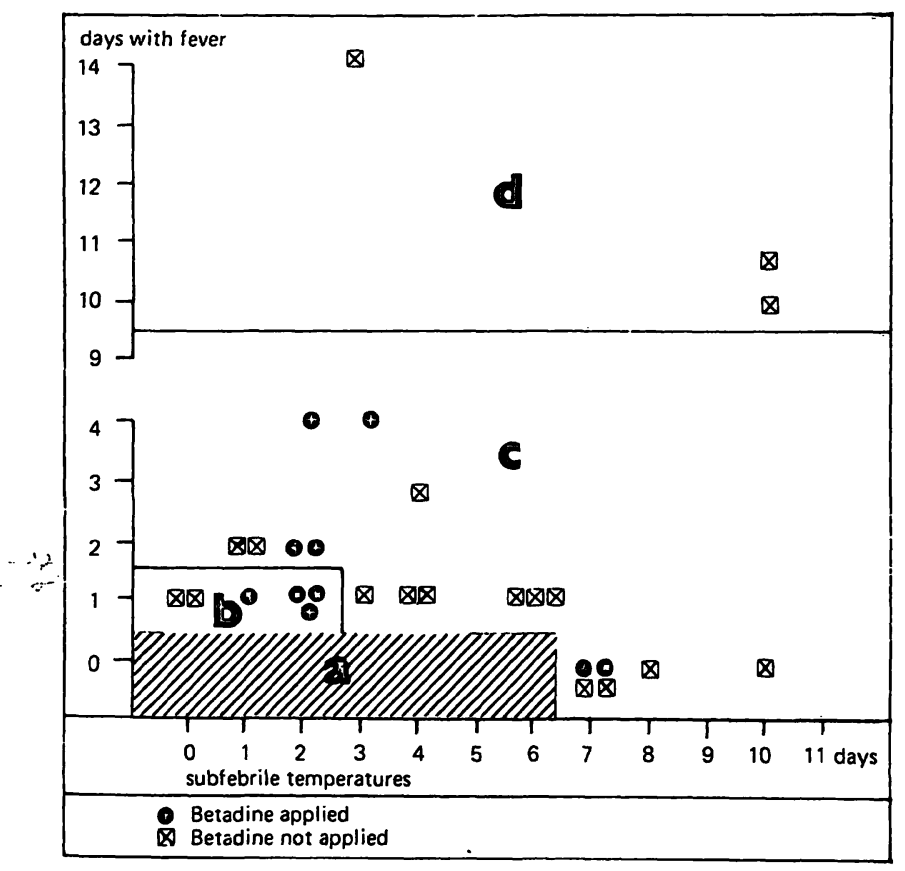

Fig. 3. Postpartum morbidity. Ordinate: cases with fever; abscissa: cases with subfebrile temperatures. Duration of fever is indicated in days.

Example: in the case on top of the graph, the patient had fever for 14 days and was subfebrile for 3 days. atures of six days while the most severe Group d was comprised of cases with fever of ten days and longer. In between are Groups $b$ and $c$. The $\chi^{2}$-Test shows significant differences in favor of the patients treated with Betadine. It is also seen that the duration of the fever was only 2.0 days in patients with Betadine administration as opposed to 3.8 days in women without Betadine (Tab. III).

The mean duration in cases of subfebrile temperatures was 2.0 and 2.7 days. An analysis of cases receiving antibiotics is seen in Tab. IV. In both groups most of the cases received the antibiotic in order to protect the fetus because of a fever which occurred during birth. Consequently this antibiotic was continued post-partum. In the cases receiving antibiotics it was seen that the antibiotics were given 4.5 days on the average to patients with Betadine application as opposed to 6.9 days in the others. The mean duration of post-partum fever was lower in patients with Betadine application. The total number of patients receiving antibiotics is low demonstrating our relatively strict indication for their use.

Neonatal morbidity was also analysed. In neither group were there cases of serious infections. Interesting was the number of scalp infections following fetal blood analyses and at the 
Tab. III. Tabulation of the total number of febrile days and the total number of days with subfebrile temperatures and calculation of the averages per patient.

\begin{tabular}{lllllll}
\hline Betadine & $\begin{array}{l}\text { No. of cases } \\
\text { with fever } \\
1 \text { day }\end{array}$ & $\begin{array}{l}\text { Total No. of } \\
\text { febrile days }\end{array}$ & $\begin{array}{l}\text { Febrile days } \\
\text { per patient }\end{array}$ & $\begin{array}{l}\text { No. of cases } \\
\text { with subfebrile } \\
\text { temperature } \\
\geqslant 1 \text { day }\end{array}$ & $\begin{array}{l}\text { Total No. of } \\
\text { subfebrile days }\end{array}$ & $\begin{array}{l}\text { Subfebrile days } \\
\text { per patient }\end{array}$ \\
\hline Applied & 8 & 16 & $\overline{\mathrm{x}}=2.0$ & 70 & 141 & $\overline{\mathrm{x}}=2.0$ \\
Not applied & 14 & 50 & $\overline{\mathrm{x}}=3.8$ & 66 & 180 & $\overline{\mathrm{x}}=2.7$ \\
\hline
\end{tabular}

Tab. IV. Cases receiving antibiotics.

\begin{tabular}{llllcllll}
\hline & $\begin{array}{l}\text { No. of } \\
\text { cases } \\
\text { with } \\
\text { anti- } \\
\text { biotics }\end{array}$ & \% of total & & $\begin{array}{l}\text { Indication } \\
\text { Fever } \\
\text { during } \\
\text { labor }\end{array}$ & $\begin{array}{l}\text { Post- } \\
\text { partum } \\
\text { fever }\end{array}$ & $\begin{array}{l}\text { Total No. of Days per } \\
\text { patient-anti- patient } \\
\text { biotic days }\end{array}$ & $\begin{array}{l}\text { Total No. } \\
\text { of post- } \\
\text { partum } \\
\text { febrile } \\
\text { days }\end{array}$ & $\begin{array}{l}\text { Febrile } \\
\text { days per } \\
\text { patient }\end{array}$ \\
\hline Given & 6 & 4.7 & 5 & 1 & 27 & $\bar{x}=4.5$ & 2 & $\bar{x}=2$ \\
Not given & 8 & 6.6 & 5 & 3 & 55 & $\bar{x}=6.9$ & 12 & $\bar{x}=4$ \\
\hline
\end{tabular}

Tab. V. Neonatal morbidity.

\begin{tabular}{llll}
\hline Betadine & $\begin{array}{l}\text { No. of analyzed } \\
\text { cases }\end{array}$ & $\begin{array}{l}\text { No. of infants with } \\
\text { infected electrode or } \\
\text { sampling sites on } \\
\text { scalp (2 each) }\end{array}$ \\
\hline Applied & $\mathrm{n}$ & $\mathrm{n}$ & $\%$ \\
& 127 & 0 & 0 \\
\hline Not applied & 122 & 4 & 3.3 \\
\hline
\end{tabular}

sites of electrode application (Tab. V). This again demonstrates that the risk for even these minor infections is notably less following the use of Betadine.

These first results allow the conclusion that the method described here can result in a decreased risk of intrapartum infection. While this certainly does not adequately answer all problems of obstetric infectious disease, the method appears suitable for further development.

There were no important side effects or disadvantages from the use of Betadine. At the most a certain dryness of the vagina was observed which was clinically insignificant.

\section{Summary}

The introduction of intensive intrapartum monitoring has led to an increased risk of ascending infections (Fig. 1). Because of the potential spread of hospital infections the prophylactic use of antibiotics is not appropriate. A new method is described which is suitable to combat the ascension of organisms without promoting the spread of resistant organisms in hospitals.

At the beginning of the intensive monitoring a plastic catheter attached to the fetal scalp electrode is applied
(Fig. 2). Through this catheter a well tolerated disinfectant solution is perfused out through the birth canal throughout the entire labor. The disinfectant used is an organic iodine complex (Betadine $R$ ). This preparation avoids the disadvantages of free iodine while maintaining full disinfectant activity and it is particularly well tolerated. From August through December 1976 this method was used in alternating patients admitted with a cervical dilatation of $4 \mathrm{~cm}$ and less. The neonatal and maternal 
post-partum morbidity was compared. In cases with a latent period between ruptured membranes and Betadine application of less than 3 hours, the Betadine patients ( $n=127$ cases) as opposed to the group without Betadine ( $n=122$ patients) demonstrated marked differences in regard to the increasing severity of morbidity (Tab. II, Fig. 3). A $x^{2}$-test demonstrated a significantly better outcome in cases treated with Betadine. In addition patients who had received the Betadine treatment had fever of less duration (Tab. III).
Antibiotics were used in only 5-7\% in both groups, primarily because of intrapartum fever. The average duration of the antibiotic course was 4.5 days for patients with Betadine and 6.9 days for patients without (Tab. IV). Neonatal morbidity was low in both groups but the local infections associated with scalp sampling and electrode application was less in infants whose mothers had been in the Betadine group.

The first results allow the conclusion that the described method is useful in the decreasing of risk of intrapartum infections.

Keywords: Betadine, danger of infection, intensive surveillance, reduction of risks.

\section{Zusammenfassung}

Ein neuer Weg zur Senkung der subpartualen Infektionsgefährdung

Die Einfuihrung der Intensivüberwachung sub partu hat zu einer Erhöhung der Gefahr von aszendierenden Infektionen geführt (Abb. 1). Der prophylaktische Einsatz von Antibiotika stellt wegen der Förderung des Hospitalismus keine sinnvolle Lösung dar. Ein neues Vorgehen ist erprobt worden, welches gestattet, die Keimaszension zu bekämpfen, den Hospitalismus aber nicht zu fördern.

$\mathrm{Zu}$ Beginn der Intensivüberwachung wird mit Anbringen der Kopfschwartenelektrode zur Durchführung der Kardiotokographie gleichzeitig ein dünner, an der Elektrode haftender Kunststoffkatheter eingeführt (Abb. 2). Über diesen Katheter wird während des gesamten Geburtsgeschehens eine gut verträgliche Desinfektionslösung langsam herausgepumpt, wobei die Geburtswege, bis außen zur Vulva hin, ständig mit der Lösung benetzt werden. Erprobt wurde eine organische Jod-Komplex-Verbindung: Betadine (BetaisodonaR). Die desinfizierende Wirksamkeit dieses Präparates ist voll erhalten, ohne daß die Nachteile des freien Jods sich auswirken. Das Präparat ist außerordentlich gut verträglich.

Von August bis Dezember 1976 wurde in einer alternierenden Reihe bei Kreißenden mit einer Muttermundsweite von $4 \mathrm{~cm}$ und weniger dieses Verfahren angewandt, wobei sowohl die Morbidität der Mütter im Wochenbett, als auch die der Neugeborenen gegenübergestellt wurde.
In Fällen, in denen die Latenzzeit zwischen vorausgegangenem Blasensprung und Beginn oder möglichem Beginn der Betadine-Applikation weniger als 3 Stunden betrug, zeigen sich im Kollektiv mit Betadine-Anwendung ( $n=127$ Fälle) gegenüber dem Kollektiv ohne BetadineAnwendung ( $\mathrm{n}=122$ Fälle) deutliche Unterschiede bei zunehmendem Schweregrad der Morbịdität (Tab. II, Abb. 3). Der $x^{2}$-Test zeigte bei einseitiger Betrachtung signifikante Unterschiede zugunsten der mit Betadine behandelten Patientinnen. Auch zeigte sich, daß Patientinnen, die Fieber oder subfebrile Temperaturen hatten, diese im Durchschnitt bei Frauen ohne Applikation von Betadine länger anhielten (Tab. III).

Antibiotika wurden in beiden Kollektiven nur in 5-7\% aller Fälle, hauptsächlich wegen sub partu aufgetretenen Fiebers verabfolgt. Die durchschnittliche Dauer der Antibiotika-Gabe betrug bei Patientinnen mit BetadineApplikation 4,5 und ohne 6,9 Tage (Tab. IV).

Die Morbidität der Kinder wurde ebenfalls ausgewertet (Tab. V). Hieraus geht ebenfalls hervor, daß die Infektionsgefährdung, wenn es sich hierbei auch mehr um banale lokale Infekte handelt, nach Betadine-Applikation geringer ist.

Aus den ersten Ergebnissen läßt sich bereits der Schluß ziehen, daß mit dem beschriebenen Verfahren der subpartualen Infektionsbekämpfung eine Risikominderung zu erzielen ist.

Schlüsselwörter: Betadine, Infektionsgefahr, Intensivüberwachung, Risikoverminderung.

Résumé

${ }^{2}$ Nouvelles méthodes de réduction des risques d'infection subpartuale

L'introduction de la surveillance intensive sub partu a provoqué une augmentation des risques d'infections ascendantes (Fig. 1). L'application prophylactique d'antibiotiques ne représente pas la bonne solution, car elle nécessite l'hospitalisation. Une nouvelle méthode a donc été expérimentée pour permettre de combattre la montée germinative sans hospitalisation.

$\mathrm{Au}$ début de la surveillance intensive, on fixe une électrode sur le cuir chevelu pour la cardiotocographie et on introduit en même temps un cathéter plastique adhérent à l'électrode (Fig. 2). Pendant toute la durée de l'accouchement, on injecte lentement par ce cathéter une solution désinfectante bien tolérée afin d'humecter en permanence les voies génitales jusqu'à la vulve. On a expérimenté à cet égard la bétadine (Bétaisodona $R$ ), un composé organique de complexe-iode. L'efficacité désinfectante de cette substance reste intacte sans que se manifestent les inconvénients de l'iode libre. La préparation est parfaitement tolérée.

D'août à décembre 1976 cette méthode a.été appliquée dans une série alternée de femmes en travail avec une ouverture de l'orifice de l'utérus de $4 \mathrm{~cm}$ et moins et avec annotation de la morbidité des mères en couches ainsi que des nouveaux-nés. Dans les cas où la durée latente entre la rupture des membranes et le début possible ou réel de l'application de bétadine a été inférieure à trois heures, on 
a pu observer des différences très nettes de gravité croissante de morbidité entre les groupes traités à la bétadine $(n=$ 127 cas) et non traités ( $n=122$ cas) (Tab. II, Fig. 3). Le Test $x^{2}$ a montré à l'observation unilatérale des différences significatives favorables aux parturientes traitées à la bétadine. De même, on a pu noter que les parturientes qui avaient de la fièvre ou une température subfébrile ont retrouvé en général plus rapidement une température normale sous administration de bétadine (Tab. III). Les antibiotiques n'ont été donnés dans les deux groupes que dans 5 à $7 \%$ des cas, en présence surtout de fièvre sub partu. La durée moyenne de l'administration d'antibiotiques a été de 4,5 jours pour les parturientes avec bétadine et de 6,9 jours pour les au tres (Tab. IV).

La morbidité des enfants a été également évaluée (Tab. V) et on a pu observer que le danger d'infection - même s'il s'agit ici davantage d'infections locales peu importantes est moins grand après administration de bétadine.

Les premiers résultats montrent donc qu'il est possible de réduire les risques d'infection sub partuale en recourant au traitement décrit ci-dessus.

Mots-clés: Bétadine, danger d'infection, réduction des risques, surveillance intensive.

\section{Bibliography}

[1] ALDEN, E. R., P. V. CAPOROSSI, G. C. LATHAM, R. G. SCHERZ: Effect of prenatal povidone-iodine perineal antisepsis on serum protein-bound iodine. Obstet. Gynec. 35 (1970) 253

[2] BADEN, W. F., J. Q. THOMPSON, T. A. WALKER, M. ARDJOMAD: Cervical iodine test. Alternation of protein-bound iodine and radioactive iodine uptake determinations. Obstet. Gynec. 36 (1970) 745

[3] BERNARD, I.: Utilisation de Bétadine solution en gynécologie. Bordeaux Méd. 3 (1973) 367

[4] BHASKAR RAO, K., G. SWAMIDASAN, G. VIMLA: Chorioamnionitis. J. Obstet. Gynaec. of India. Vol. XVI, No. 2 (1966)

[5] BOGASH, R. C.: A new iodophor disinfectant, survey and evaluation. Bull. Amer. Soc. Hosp. Pharmacists 12 (1955) 135

[6] BOTZENHART, K., E. SPENGLER, J. SCHNEIDER: Untersuchungen zur präoperativen Hautdesinfektion mit einem Jodophor. Fortschr. Med. 93 (1975) 345

[7] BRENMAN, H. S., E. RANDALL: Local degerming with povidone-iodine. II. Prior to gingivectomy. J. Periodontol. 45 (1974) 870

[8] CHAN, W. H., R. H. PAUL, J. TOEWS: Intrapartum fetal monitoring - Maternal and fetal morbidity and perinatal mortality. Obstet. Gynec. 41 (1973) 7

[9] DAHLER, R., K. BECKER, H. A. HIRSCH: Bakterielle Besiedlung des Fruchtwassers unter der Geburt. Perinatale Medizin VI. Thieme, Stuttgart 1975

[10] DUIGNAN, N. M., P. A. LOWE: Pre-operative disinfection of the vagina. J. Antimicrob. Chemother. 1 (1975) 117

[11] FISCHER, W. M., H. LUDWIG: Vorzeitiger Blasensprung, aszendierende intrauterine Infektion und ihre Gefahren für den Feten und das Neugeborene. Perinatale Medizin IV. Thieme, Stuttgart 1973

[12] GASSNER, C. B., W. J. LEDGER: The relationship of hospital acquired maternal infections to invasive intrapartum monitoring techniques. Amer. J. Obstet. Gynec. 126 (1976) 33

[13] GUIGNIER, M., C. BRAMBILLA, A. BRABANT, J.-L. DEBRU, J.-L. HERNANDEZ, C. PIRCHER, J. M. MULLER: Les lavages peritoneaux à la polyvinylpyrrolidone iodée. A propos de 11 cas. Nouvelle Presse Méd. 3 (1974) 1559
[14] HAUSER, G. A.: Neues, die Döderleinflora schonendes Vaginaldesinfiziens zur Therapie unspezifischer Vaginitiden. Schweiz. Rundschau Med. (Praxis) 64 (1975) 1289

[15] HIRSCH, H. A.: Infektionen in der Geburts- und Perinatal-Medizin (Peripartale diagnostische Eingriffe). In preparation.

[16] KNOLLE, P.: Alt und aktuell - Keime und Jod. Hospital-Hygiene, Gesundheitswesen und Desinfektion 67 (1975) 389

[17] LANG, R., K. DECKER, O. DAUBENFELD, H. A. HIRSCH: Bakterielle Besiedlung des Fruchtwassers unter der Geburt. 2. Einfluß der systematischen Antibiotikaprophylaxe. Perinatale Medizin VI. Thieme, Stuttgart 1975

[18] MANEKSHA, S.: Comparison of Povidone-lodine (Betadine) vaginal pessaries and lactic acid pessaries in the treatment of vaginitis. J. Int. Med. Res. 2 (1974) 236

[19] MUlleR, H., F. KUBLI: Das Amnioninfektionssyndrom und die vorzeitige Amnionruptur - Die manifesten und die drohenden unspezifischen intrauterinen Infektionen des letzten Schwangerschaftsdrittels. Z. Geburtsh. u. Perinat. 179 (1975) 77

[20] POSTLEThWAIT, R. W., M. L. DilloN: Iodophor for presurgical skin antisepsis. Arch. Surg. 89 (1964) 462

[21] REEVE, E. S., G. A. E. COUPLAND, I. B. HALES: The effect on serum-iodine levels of painting tincture of iodine on the skin. Med. J. Australia 1 (1973) 891

[22] SHELANSKI, H. A., M. V. SHELANSKI: PVP-iodine: History, toxicity and therapeutic uses. J. Int. Coll. Surgeons 25 (1956) 727

[23] SHOOK, D. M.: A clinical study of a povidoneiodine regimen for resistant vaginitis. Curr. Therap. Res. 5 (1963) 256

[24] THURER, R. J., D. BOGNOLO, A. VARGAS, J. H. ISCH, G. A. KAISER: The management of mediastinal infection following cardiac surgery. An experience utilizing continuous irrigation with povidone-iodine. J. Thorac. Cardiovasc. Surg. 68 (1974) 962 
[25] ZINNAGL, N.: Non-specificpost-gonorrheal urethritis cured with betaisodona (betadine) solution. Abstr. M-205, 9th Int'1 Congr. of Chemotherapy. London (1975)
[26] ZINNER, D. D., J. M. JABLON, M. S. SASLAW: Bactericidal properties of povidone-iodone and its effectiveness as an oral antiseptic. Oral Surg. Oral Med. Pathol. 14 (1961) 1377

Received and accepted September 19, 1977.

Prof. Dr. med. E. Saling

Mariendorfer Weg 28

D-1000 Berlin 44 